ISSN 0258-7122

Bangladesh J. Agril. Res. 38(4): 689-704, December 2013

\title{
INFLUENCE OF SEED RATES AND LEVELS OF NPK FERTILIZERS ON DRY MATTER ACCUMULATIONS AND YIELD PERFORMANCE OF FOXTAIL MILLET (Setaria italica L. Beauv.)
}

\author{
M. S. HASAN ${ }^{1}$, M. H. RASHID ${ }^{2}$, Q. A. RAHMAN ${ }^{4}$ AND M. H. AL-MAMUN ${ }^{3}$
}

\begin{abstract}
A study was carried out in the Agronomy Field Laboratory, Bangladesh Agricultural University, Mymensingh, Old Brahmaputra Flood Plains Soil (AEZ-9) during December 2001 to April 2002 to find out the effect of seed rates and NPK levels on dry matter accumulation and grain yield of foxtail millet (Setaria italica L. Beauv.). Four seed rates viz., 8,10,12, and $14 \mathrm{~kg} / \mathrm{ha}$ and five levels of NPK fertilizers viz., $\mathrm{N}_{0} \mathrm{P}_{0} \mathrm{~K}_{0}, \mathrm{~N}_{10} \mathrm{P}_{8} \mathrm{~K}_{5}, \mathrm{~N}_{20} \mathrm{P}_{16} \mathrm{~K}_{10}, \mathrm{~N}_{30} \mathrm{P}_{24} \mathrm{~K}_{15}$, and $\mathrm{N}_{40} \mathrm{P}_{32} \mathrm{~K}_{20}$ were included in a split plot design with three replications. Dry matter accumulation pattern was determined by harvesting 10 plants randomly at 30, 60, 80, and 102 DAS (days after swing). The yield and yield contributing characters of foxtail millet were influenced by seed rates and NPK levels except tillers per plant and 1000-grain weight significantly. Generally its production rate was $0.86 \mathrm{t} / \mathrm{ha}$ when it was grown in char lands in sandy loam soils, the highest grain yield (1.62 t/ha) was produced by $10 \mathrm{~kg}$ seeds/ha, which was identical with $12 \mathrm{~kg}$ seeds/ha. In case of NPK levels, the treatment was $\mathrm{N}_{30} \mathrm{P}_{24} \mathrm{~K}_{10}$. In case of interaction, the treatment combination $12 \mathrm{~kg}$ seeds/ha and $\mathrm{N}_{30} \mathrm{P}_{24} \mathrm{~K}_{15}$ produced the highest grain yield (1.77 t/ha. In case of interaction, the treatment combination $12 \mathrm{~kg}$ seeds/ha and $\mathrm{N}_{30} \mathrm{P}_{24} \mathrm{~K}_{15} /$ ha gave the highest grain yield.
\end{abstract}

Keywords: Seed rates, NPK fertilizers, dry matter, yield and yield contributing characters, foxtail millet.

\section{Introduction}

Foxtail millet (Setaria italica L. Beauv.) commonly known as 'Kaon' is an important minor cereal crops in Bangladesh. It is also known as Italian millet or German millet which was originated in North China where it was an important cereal till the introduction of wheat and Lorelei (FAO, 1985). In Bangladesh, it can be grown in both rabi and kharif seasons, but it grows better in rabi season. Although low yielding, its short duration and drought tolerance along with lowinput requirements ensure its bright prospects under the existing rainfed farmers cropping system (Mannujan et al., 1990). Foxtail millet, a drought resistant

\footnotetext{
${ }^{1}$ Senior Scientific Officer, Jute Farming Systems Division, ${ }^{2}$ Senior Scientific Officer, Breeding Division, ${ }^{3}$ Senior Scientific Officer, Farm Management Unit, Bangladesh Jute Research Institute (BJRI), Manik Mia Avenue, Dhaka-1207, ${ }^{4}$ Scientific Officer, Olericulture Division, Horticulture Research Center, Bangladesh Agricultural Research Institute (BARI), Gazipur-170l, Bangladesh.
} 
cereal crop, is extensively cultivated on marginal lands and river beds in Bangladesh where high yielding crops can not be grown profitably. It grows @ $0.86 \mathrm{t} / \mathrm{ha}$ (BARI, 1990) in light textured soils due to its genotypic potentiality under adverse condition. The average yield of the crop is low in this country and it can be attributed to low soil fertility, poor management practices, and lack of use of high yielding modern varieties. The farmers generally do not use fertilizers in the cultivation of foxtail millet. Millets are generally grown on frequently emergencies following crops like transplant Aman failure from unfavourable condition like floods and drought. The area under 'Kaon' has been considerably reduced in Bangladesh due to the expansion of HYV wheat and Boro rice and development of irrigation facilities. Foxtail millet may be grown in 'char' areas and also where farmers do not have any scope of irrigation during the post monsoon period, particularly in the river basin in Bangladesh. From nutritional point of view, it is good for health and can increase the life span of human being (Takanohashi, 1993).

Foxtail millet can be stored for a long time without much damage from insect pests (Coscia, 1983). Because of this merit, it plays the role of an emergency crop in the year of bad harvest. Non-adaptation of improve varieties and ultimately use of cultural operations like time of sowing, seed rates, weeding, interculural operations, irrigation facilities, pest and disease management, etc. are the important constraints to achieve higher productivity in millets (Hedge and Gowda, 1986). Adequate information is not available, but as it appears, at least 19,443 hectares of land are put under foxtail millet cultivation every year and its production is about 15,000 $\mathrm{m}$ tons (BBS, 1993). People of different areas of Bangladesh grow it without any recommended seed rates and fertilizers doses which results in low grain yield. It may be possible to increase the yield of foxtail millet by using the appropriate combination of seed rate and NPK fertilizer dose. Optimum seed rate ensures normal plant growth because of efficient utilization of moisture, light, uptake of nutrient elements and thus increase the yield of crop. The present study was conducted to evaluate the effect of different seed rates and levels of NPK fertilizer and to determine the optimum combination of seed rate and NPK fertilizer for optimum growth, development and maximum yield of foxtail millet.

\section{Materials and Method}

Titas, a cultivar of foxtail millet used for the study was developed by Bangladesh Agricultural Research Institute (BARI), Joydebpur, Gazipur. Pure seeds of Titas were collected from the Agronomy Division, BARI. The experimental plot was sited at the Agronomy field Laboratory, Bangladesh Agricultural University, Mymensingh. The topography of the experimental land was medium high and the soil was sandy loam in texture belonging to non-Calcareous Dark Grey 
Floodplain soil. The soil is moderately acidic in nature, moderate in organic matter content and general fertility is low, status of $\mathrm{P}$ and cation exchange capacity are medium, $\mathrm{K}$ and $\mathrm{N}$ status of soils are low (BARC, 1989). Four seed rates $8,10,12$, and $14 \mathrm{~kg} / \mathrm{ha}$ and five levels of NPK fertilizers viz., $\mathrm{N}_{0} \mathrm{P}_{0} \mathrm{~K}_{0}$ $\mathrm{N}_{10} \mathrm{P}_{8} \mathrm{~K}_{5}, \mathrm{~N}_{20} \mathrm{P}_{16} \mathrm{~K}_{10}, \mathrm{~N}_{30} \mathrm{P}_{24} \mathrm{~K}_{15}$, and $\mathrm{N}_{40} \mathrm{P}_{32} \mathrm{~K}_{20}$ were included in a split plot design with three replications. Each replication was divided into 20 plots assigning four seed rates in the main plots and four levels of NPK fertilizer in the sub-plots. The whole experiment comprises of $60(3 \times 20)$ unit plots. The size of unit plot was $(4 \times 2.50 \mathrm{~m}) 10 \mathrm{~m}^{2}$. The plot to plot distance was $0.75 \mathrm{~m}$ and that from replication to replication was $1 \mathrm{~m}$. Nitrogen, phosphorus, and potassium were applied through urea, TSP, and MP as per schedule of the experiment, respectively. The entire amount of the TSP, MP, and one-third of urea were applied at the time of final land preparation. The rest of urea was applied in two equal splits at 30 and 60 days after sowing (DAS). Seeds of Kaon were sown in lines in the furrows at the rate of $8,10,12$, and $14 \mathrm{~kg} / \mathrm{ha}$ as per treatment schedule. Furrows of about $3 \mathrm{~cm}$ depth were opened by hand rake and line to line distance was $25 \mathrm{~cm}$. After sowing, the seeds were covered by well pulverized soil followed by a light pressure by hand. Seeds were germinated within 6-7 days after sowing. After 30 DAS, $1^{\text {st }}$ weeding was done in each plot, while the another one was operated at 60 DAS followed by top dressing of urea fertilizer. When the crop was found under moisture stress, irrigation was given on 13 February, 2002. The crop was infested by grasshopper, shoot fly, ear cutworm, etc. at late vegetative stage. It was successfully controlled by growth period and as such no fungicidal spray was needed. All possible plant protection measures were taken as and when necessary. Observations were recorded on 10 randomly selected plants in each plot for dry matter accumulation at 30, 60, 80 DAS and at harvest. Observation on yield and yield contributing characters were also made. The collected data were analyzed and the mean differences were adjusted by the Duncan's Multiple Range Test (DMRT).

\section{Results and Discussion}

\section{A. Effects of seed rates and NPK levels on dry matter accumulation}

Dry matter of leaves increased more or less up to 80 DAS and afterwards slightly decreased probably due to shedding effect of older leaves (Table 1). However, there was an inverse relationship between seed rates and dry matter accumulation of foxtail millet leaves at all stages of sampling. On the other hand, there was parallel relationship between levels of NPK application and dry matter accumulation of foxtail millet. Result showed that dry matter accumulation varied significantly at all dates of sampling due to seed rates and NPK levels. Leaf dry matter (g/plant) accumulation decreased with increasing seed rates and 
increased with increasing levels of NPK. At harvest, the levels $\mathrm{N}_{40} \mathrm{P}_{32} \mathrm{~K}_{20} \mathrm{~kg} / \mathrm{ha}$ and seed rates $8 \mathrm{~kg} /$ ha produced the maximum leaf dry matter of $5.175 \mathrm{~g} / \mathrm{plant}$ and $5.332 \mathrm{~g}$ /plant, respectively. Leaf dry matter accumulation increased till 80 DAS and afterward tended to decline (Table 1). After anthesis, development of new leaves stopped and perhaps photosynthates remobilized to the grains. Remobilization of photosynthesis for meeting the sink demand might have reduced leaf dry matter which are in agreement with that of Benner and Bazzaz, 1988. The results revealed that dry matter accumulation in leaf was relatively high at maximum tillering stage. After that, the dry matter was diverted for panicle formation and its developments. Interaction of seed rate and levels of NPK on leaf dry matter was significant at all stages (Table 2).

Table 1. Effects of seed rates and different levels of NPK on leaf dry matter accumulation of foxtail millet.

\begin{tabular}{|c|c|c|c|c|}
\hline \multirow{2}{*}{$\begin{array}{c}\text { Treatments } \\
\begin{array}{c}\text { Seed rates } \\
(\mathrm{kg} / \mathrm{ha})\end{array}\end{array}$} & \multicolumn{4}{|c|}{ Leaf dry matter (g/plant) } \\
\hline & $\begin{array}{c}30 \text { DAS } \\
\text { (At vegetative } \\
\text { stage) }\end{array}$ & $\begin{array}{c}60 \text { DAS } \\
\text { (At flowering } \\
\text { stage) }\end{array}$ & $\begin{array}{c}80 \text { DAS } \\
\text { (At dough } \\
\text { stage) }\end{array}$ & $\begin{array}{c}102 \text { DAS } \\
\text { (At } \\
\text { harvest) }\end{array}$ \\
\hline 8 & $0.062 \mathrm{a}$ & $1.075 \mathrm{ab}$ & 3.798 a & $5.332 \mathrm{a}$ \\
\hline 10 & $0.065 \mathrm{a}$ & $1.128 \mathrm{a}$ & $3.878 \mathrm{~b}$ & $4.868 \mathrm{ab}$ \\
\hline 12 & $0.042 b$ & $1.012 \mathrm{~b}$ & $3.644 a$ & 5.136ab \\
\hline 14 & $0.049 \mathrm{~b}$ & $0.847 \mathrm{c}$ & $3.032 \mathrm{~b}$ & $5.000 \mathrm{~b}$ \\
\hline Level of Significance & 0.0002 & 0.0003 & 0.0021 & 0.0239 \\
\hline Sx & 0.0017 & 0.0200 & 0.0902 & 0.0764 \\
\hline CV (\%) & 12.31 & 9.36 & 9.73 & 5.82 \\
\hline \multicolumn{5}{|l|}{ Fertilizes (kg/ha) } \\
\hline $\mathrm{N}_{0} \mathrm{P}_{0} \mathrm{~K}_{0}$ & $0.049 \mathrm{~b}$ & 0.907 c & $3.232 b$ & $4.893 \mathrm{c}$ \\
\hline $\mathrm{N}_{10} \mathrm{P}_{8} \mathrm{~K}_{5}$ & $0.050 \mathrm{~b}$ & 0.963 bc & $3.345 \mathrm{~b}$ & $4.958 b \mathrm{c}$ \\
\hline $\mathrm{N}_{20} \mathrm{P}_{16} \mathrm{~K}_{10}$ & $0.057 \mathrm{ab}$ & $1.155 \mathrm{a}$ & 3.875 a & $5.245 \mathrm{a}$ \\
\hline $\mathrm{N}_{30} \mathrm{P}_{24} \mathrm{~K}_{15}$ & $0.057 \mathrm{ab}$ & $0.986 \mathrm{bc}$ & 3.875 a & 5.150 abc \\
\hline $\mathrm{N}_{20} \mathrm{P}_{16} \mathrm{~K}_{10}$ & $0.057 \mathrm{ab}$ & $1.155 \mathrm{a}$ & $3.875 \mathrm{a}$ & $5.245 \mathrm{a}$ \\
\hline $\mathrm{N}_{30} \mathrm{P}_{24} \mathrm{~K}_{15}$ & $0.057 \mathrm{ab}$ & 0.986 be & 3.875 a & $5.150 \mathrm{abc}$ \\
\hline $\mathrm{N}_{40} \mathrm{P}_{32} \mathrm{~K}_{20}$ & $0.060 \mathrm{a}$ & $1.066 \mathrm{ab}$ & 3.753 a & $5.175 \mathrm{ab}$ \\
\hline Level of significance & 0.0009 & 0.0100 & 0.0002 & 0.0280 \\
\hline Sx & 0.0019 & 0.0224 & 0.1008 & 0.0854 \\
\hline CV(\%) & 12.31 & 9.63 & 9.73 & 5.82 \\
\hline
\end{tabular}

In a column, figures having common letter (s) do not differ significantly. 
Table 2. Effect of interaction of seed rates and different levels of NPK on leaf dry matter accumulation of foxtail millet.

\begin{tabular}{|c|c|c|c|c|}
\hline $\begin{array}{c}\text { Interaction of seed } \\
\text { rates } x \text { levels of NPK }\end{array}$ & 30 DAS & 60 DAS & 80 DAS & 102 DAS \\
\hline $\mathrm{S}_{1} \mathrm{~F}_{0}$ & 0.050 cdef & $1.250 \mathrm{~b}$ & 3.360 def & 5.550 \\
\hline $\mathrm{S}_{1} \mathrm{~F}_{1}$ & 0.050 cdef & $1.120 \mathrm{~b}$ & 4.180 abc & 5.120 \\
\hline $\mathrm{S}_{1} \mathrm{~F}_{2}$ & 0.046 def & 1.060 bce & $2.680 \mathrm{fg}$ & 5.510 \\
\hline $\mathrm{S}_{1} \mathrm{~F}_{3}$ & 0.050 cdef & 1.130 bcdef & $4.450 \mathrm{ab}$ & 5.570 \\
\hline $\mathrm{S}_{1} \mathrm{~F}_{4}$ & 0.047 def & $0.813 \mathrm{bcd}$ & 4.320 abc & 4.910 \\
\hline $\mathrm{S}_{2} \mathrm{~F}_{0}$ & $0.073 \mathrm{a}$ & 0.390 ghi & 3.270 defg & 4.900 \\
\hline $\mathrm{S}_{2} \mathrm{~F}_{1}$ & 0.050 bcde & 1.140 hij & $40390 \mathrm{ab}$ & 5.030 \\
\hline $\mathrm{S}_{2} \mathrm{~F}_{2}$ & $0.070 \mathrm{ab}$ & $1.770 \mathrm{bcd}$ & $4.540 \mathrm{a}$ & 4.470 \\
\hline $\mathrm{S}_{2} \mathrm{~F}_{3}$ & $0.050 \mathrm{ab}$ & 0.85 a & 4.110 abc & 4.950 \\
\hline $\mathrm{S}_{2} \mathrm{~F}_{4}$ & $0.077 \mathrm{a}$ & 1.190 fghi & 3.080 efg & 4.990 \\
\hline $\mathrm{S}_{3} \mathrm{~F}_{0}$ & 0.037 efg & $1.030 \mathrm{bc}$ & 3.690 cde & 4.880 \\
\hline $\mathrm{S}_{3} \mathrm{~F}_{1}$ & $0.033 \mathrm{fg}$ & 0.990 bcde & $2.610 \mathrm{~g}$ & 4.790 \\
\hline $\mathrm{S}_{3} \mathrm{~F}_{2}$ & 0.043 efg & 0.910 cdef & $2.990 \mathrm{fg}$ & 5.070 \\
\hline $\mathrm{S}_{3} \mathrm{~F}_{3}$ & $0.027 \mathrm{~g}$ & 0.9900 defgh & $3.311 \mathrm{def}$ & 4.800 \\
\hline $\mathrm{S}_{3} \mathrm{~F}_{4}$ & $0.070 \mathrm{ab}$ & $1.230 \mathrm{bc}$ & $4.420 \mathrm{ab}$ & 6.140 \\
\hline $\mathrm{S}_{4} \mathrm{~F}_{0}$ & $0.067 \mathrm{abc}$ & $0.660 \mathrm{ij}$ & 3.810 bcd & 4.330 \\
\hline $\mathrm{S}_{4} \mathrm{~F}_{1}$ & 0.063 abcd & $0.600 \mathrm{j}$ & 3.120 efg & 4.800 \\
\hline $\mathrm{S}_{4} \mathrm{~F}_{2}$ & $0.067 \mathrm{abc}$ & 0.880 efgh & 3.170 defg & 5.550 \\
\hline $\mathrm{S}_{4} \mathrm{~F}_{3}$ & $0.067 \mathrm{abc}$ & 1.063 bcde & 3.070 efg & 5.660 \\
\hline $\mathrm{S}_{4} \mathrm{~F}_{4}$ & 0.047 def & 1.030 bcde & 3.190 defg & 4.660 \\
\hline Level significance & 0.00001 & 0.00001 & 0.00001 & NS \\
\hline Sx & 0.0039 & 0.0447 & 0.2017 & 0.1708 \\
\hline CV (\%) & 12.31 & 9.63 & 9.73 & 5.82 \\
\hline
\end{tabular}

The ear dry matter accumulation varied significantly at all dates of sampling due to seed rates, NPK levels ( Table 3) and their interaction (Table 4). It was observed that ear dry matter decreased with increasing seed rates and increased with increasing NPK levels (Table 3). Influence of NPK levels in the increment of ear weight was much striking than it was observed for vegetative organs. This was perhaps because of increased photosynthesis and greater remobilization of assimilates to the grains in the fertilizer treated plants after anthesis. After anthesis, ear dry matter increase dramatically in all the treatments. The total dry matter accumulation increase substantially due to increasing ear dry matter in spite of reduction in leaf dry weight. Ear dry matter accumulation was much 
more striking than it was observed for vegetative organs. This was perhaps because of increased photosynthesis and greater remobilization of assimilates to the grain in the fertilizer treated plants after anthesis.

Table 3. Effects of seed rates and different levels of NPK on ear dry matter accumulation of foxtail millet.

\begin{tabular}{llll}
\hline \multicolumn{1}{c|}{ Treatments } & \multicolumn{3}{c}{ Ear dry matter (g/plant) } \\
\hline $\begin{array}{c}\text { Seed rates } \\
\text { (kg/ha) }\end{array}$ & \multicolumn{1}{c}{$\begin{array}{c}\text { 60 DAS } \\
\text { (At flowering stage) }\end{array}$} & \multicolumn{1}{c}{$\begin{array}{c}\text { 80 DAS } \\
\text { (At dough stage) }\end{array}$} & \multicolumn{1}{c}{$\begin{array}{c}102 \text { DAS } \\
\text { (At harvest) }\end{array}$} \\
\hline 8 & $0.335 \mathrm{a}$ & $2.090 \mathrm{a}$ & $5.306 \mathrm{a}$ \\
10 & $0.316 \mathrm{a}$ & $1.962 \mathrm{~b}$ & $4.728 \mathrm{~b}$ \\
12 & $0.159 \mathrm{~b}$ & $1,896 \mathrm{~b}$ & $4,452 \mathrm{c}$ \\
14 & $0.180 \mathrm{~b}$ & $1.908 \mathrm{~b}$ & 4.2440 \\
\hline Level of significance & 0.00001 & 0,0228 & 0.002 \\
$\mathrm{Sx}$ & 0.0074 & 0.0559 & 0.0735 \\
$\mathrm{CV}(\%)$ & 9.94 & 10.40 & 7.38 \\
\hline Fertilizes (kg/ha) & & & \\
$\mathrm{N}_{0} \mathrm{P}_{0} \mathrm{~K}_{0}$ & $0.198 \mathrm{~b}$ & $1.345 \mathrm{~b}$ & $2.758 \mathrm{~d}$ \\
$\mathrm{~N}_{10} \mathrm{P}_{8} \mathrm{~K}_{15}$ & $0.175 \mathrm{~b}$ & 1.5990 & 4.142 \\
$\mathrm{~N}_{20} \mathrm{P}_{16} \mathrm{~K}_{10}$ & $0.193 \mathrm{~b}$ & $2.006 \mathrm{~b}$ & $4.903 \mathrm{~b}$ \\
$\mathrm{~N}_{30} \mathrm{P}_{24} \mathrm{~K}_{15}$ & $0.348 \mathrm{a}$ & $2.577 \mathrm{a}$ & $5,717 \mathrm{a}$ \\
$\mathrm{N}_{40} \mathrm{P}_{32} \mathrm{~K}_{20}$ & $0.323 \mathrm{a}$ & 2.441 & $5.892 \mathrm{a}$ \\
\hline Level of significance & 0.00001 & 0.00001 & 0.00001 \\
Sx & 0.0071 & 0.0599 & 0.0998 \\
CV (\%) & 9,94 & 10.40 & 7.38 \\
\hline
\end{tabular}

Total dry matter accumulation also varied significantly at all dates of sampling due to seed rates, different levels of NPK, and their interaction. The highest dry matter accumulation was observed in $8 \mathrm{~kg}$ seed/ha (Table 5). The result revealed that the increase in plant population density caused considerable decrease in total matter accumulation of foxtail millet. The observed results was in agreement with the finding of Elias et al. (1979). Similarly, $\mathrm{N}_{20} \mathrm{P}_{16} \mathrm{~K}_{10} \mathrm{hg} / \mathrm{ha}$ produced the highest dry matter (Table 5). Naik et al. (1995) also reported that total dry matter production increased with increasing NPK rates. Munda et al. (1984) also reported that at maturity, nitrogen at $120 \mathrm{~kg} / \mathrm{ha}$ increased dry matter by $33.10 \%$ over no nitrogen. The highest total dry matter accumulation was found in combination $8 \mathrm{~kg}$ seed/ha and $\mathrm{N}_{30} \mathrm{P}_{24} \mathrm{~K}_{15} \mathrm{~kg} / \mathrm{ha}$ (Table 6). After anthesis total dry matter of a plant was mainly due to the dry matter accumulation of the ear when leaves in most cases started to senescence. 
Table 4. Effect of interaction of seed rates and different levels of NPK on stem dry matter accumulation of foxtail millet.

\begin{tabular}{|c|c|c|c|}
\hline $\begin{array}{c}\text { interaction of seed } \\
\text { rates x levels of NPK }\end{array}$ & $\begin{array}{c}60 \text { DAS (At } \\
\text { flowering stage) }\end{array}$ & $\begin{array}{l}80 \text { DAS (At dough } \\
\text { stage) }\end{array}$ & $\begin{array}{l}102 \text { DAS (At } \\
\text { harvest) }\end{array}$ \\
\hline $\mathrm{S}_{1} \mathrm{~F}_{0}$ & 2.11 cdef & $1.447 \mathrm{def}$ & $2.721 \mathrm{~g}$ \\
\hline $\mathrm{S}_{1} \mathrm{~F}_{1}$ & 0.312 c & 1.728 cde & $4.390 \mathrm{de}$ \\
\hline $\mathrm{S}_{1} \mathrm{~F}_{2}$ & $0.300 \mathrm{~cd}$ & 2.019 bc & $5.820 \mathrm{~b}$ \\
\hline $\mathrm{S}_{1} \mathrm{~F}_{3}$ & 0.232 cdef & 2.945 a & $6.740 \mathrm{a}$ \\
\hline $\mathrm{S}_{1} \mathrm{~F}_{4}$ & $0.622 \mathrm{~b}$ & $2.251 \mathrm{~b}$ & $4.890 \mathrm{~cd}$ \\
\hline $\mathrm{S}_{2} \mathrm{~F}_{0}$ & $0.121 \mathrm{f}$ & $1.151 \mathrm{f}$ & $2.530 \mathrm{~g}$ \\
\hline $\mathrm{S}_{2} \mathrm{~F}_{1}$ & $0.137 \mathrm{f}$ & 1.745 cde & 3.940 ef \\
\hline $\mathrm{S}_{2} \mathrm{~F}_{2}$ & 0.920 a & $2.971 \mathrm{a}$ & $6.860 \mathrm{a}$ \\
\hline $\mathrm{S}_{2} \mathrm{~F}_{3}$ & 0.027 cdef & $2.243 \mathrm{~b}$ & $5.840 \mathrm{~b}$ \\
\hline $\mathrm{S}_{2} \mathrm{~F}_{4}$ & 0.271 cde & $2.357 \mathrm{~b}$ & $6.440 \mathrm{a}$ \\
\hline $\mathrm{S}_{3} \mathrm{~F}_{0}$ & $0.140 \mathrm{f}$ & $1.410 \mathrm{def}$ & $2.930 \mathrm{~g}$ \\
\hline $\mathrm{S}_{3} \mathrm{~F}_{1}$ & $0.122 \mathrm{f}$ & $1.764 \mathrm{~cd}$ & $3.760 \mathrm{f}$ \\
\hline $\mathrm{S}_{3} \mathrm{~F}_{2}$ & $0.145 \mathrm{f}$ & $1.846 \mathrm{c}$ & $4.640 \mathrm{~d}$ \\
\hline $\mathrm{S}_{3} \mathrm{~F}_{3}$ & 0.185 def & $2.221 \mathrm{~b}$ & $5.450 \mathrm{bc}$ \\
\hline $\mathrm{S}_{3} \mathrm{~F}_{4}$ & 0.201 cdef & $2.238 \mathrm{~b}$ & 5.408 bc \\
\hline $\mathrm{S}_{4} \mathrm{~F}_{0}$ & $0.163 \mathrm{ef}$ & $1.372 \mathrm{ef}$ & $2.850 \mathrm{~g}$ \\
\hline $\mathrm{S}_{4} \mathrm{~F}_{1}$ & $0.131 \mathrm{f}$ & $1.159 \mathrm{f}$ & 4.480 de \\
\hline $\mathrm{S}_{4} \mathrm{~F}_{2}$ & 0.163 ef & $1.187 \mathrm{f}$ & 4.260 def \\
\hline $\mathrm{S}_{4} \mathrm{~F}_{3}$ & 0.170 ef & $2.901 \mathrm{a}$ & $4.840 \mathrm{~d}$ \\
\hline $\mathrm{S}_{4} \mathrm{~F}_{4}$ & 0.198 cdef & $2.920 \mathrm{a}$ & $4.790 \mathrm{~d}$ \\
\hline Level significance & 0.0010 & 0.00001 & 0.00001 \\
\hline Sx & 0.0142 & 0.1197 & 0.1990 \\
\hline CV (\%) & 9.94 & 10.40 & 7.38 \\
\hline
\end{tabular}

In a column, figures having common letter (s) do not differ significantly 
Table 5. Effects of seed rates and different levels of NPK on total dry matter accumulation of foxtail millet.

\begin{tabular}{l|l|l|l|l}
\hline \multicolumn{1}{c|}{ Treatments } & \multicolumn{4}{c}{ Total dry matter (g/plant) } \\
\hline Seed rates (kg/ha) & $\begin{array}{c}\text { 30 DAS } \\
\text { (At vegetative } \\
\text { stage }\end{array}$ & $\begin{array}{c}\text { 60 DAS } \\
\text { (At flowering } \\
\text { stage) }\end{array}$ & $\begin{array}{c}\text { 80 DAS } \\
\text { (At dough } \\
\text { stage) }\end{array}$ & $\begin{array}{c}\text { 102 DAS } \\
\text { (At harvest) }\end{array}$ \\
\hline 8 & $0.124 \mathrm{a}$ & $1.904 \mathrm{a}$ & $10.110 \mathrm{a}$ & $26.63 \mathrm{a}$ \\
10 & $0.106 \mathrm{~b}$ & $1.898 \mathrm{a}$ & $9.282 \mathrm{~b}$ & $25.14 \mathrm{~b}$ \\
12 & $0.104 \mathrm{~b}$ & $1.760 \mathrm{a}$ & $8.832 \mathrm{~b}$ & $24.34 \mathrm{bc}$ \\
14 & $0.075 \mathrm{c}$ & $1.597 \mathrm{~b}$ & 7.2020 & $23.70 \mathrm{c}$ \\
\hline Level of significance & 0.0010 & 0.0018 & 0.0010 & 0.0103 \\
\hline $\mathrm{N}_{0} \mathrm{P}_{0} \mathrm{~K}_{0}$ & $0.099 \mathrm{ab}$ & $1.680 \mathrm{~cd}$ & $7.467 \mathrm{c}$ & $21.70 \mathrm{c}$ \\
$\mathrm{N}_{10} \mathrm{P}_{8} \mathrm{~K}_{5}$ & $0.095 \mathrm{~b}$ & $1.783 \mathrm{bc}$ & $8.563 \mathrm{~b}$ & $23.18 \mathrm{~b}$ \\
$\mathrm{~N}_{20} \mathrm{P}_{15} \mathrm{~K}_{10}$ & $0.107 \mathrm{a}$ & $1.947 \mathrm{a}$ & $9.257 \mathrm{a}$ & $27.34 \mathrm{a}$ \\
$\mathrm{N}_{30} \mathrm{P}_{24} \mathrm{~K}_{15}$ & $0.106 \mathrm{a}$ & $1.636 \mathrm{~d}$ & $9.360 \mathrm{a}$ & $26.96 \mathrm{a}$ \\
$\mathrm{N}_{40} \mathrm{P}_{32} \mathrm{~K}_{20}$ & $0.105 \mathrm{a}$ & $1.902 \mathrm{ab}$ & $9.640 \mathrm{a}$ & $26.57 \mathrm{a}$ \\
\hline Level of significance & 0.0041 & 0.00001 & 0.00001 & 0.00001 \\
Sx & 0.0023 & 0.0344 & 0.1511 & 0.3706 \\
CV (\%) & 8.17 & 8.65 & 7.91 & 7.15 \\
\hline
\end{tabular}

\section{B. Effect on yield and yield contributing characters}

The effect of seed rates on plant height was significant. The highest plant height $(106.02 \mathrm{~cm})$ was recorded from the seed rate $12 \mathrm{~kg} / \mathrm{ha}$ whereas, the lowest $(101.14 \mathrm{~cm}$ ) was noted from the seed rate $14 \mathrm{~kg} / \mathrm{ha}$ (Table 7). The observed result is in agreement with the findings of (BARI, 1985). They observed that seed rates had significant effect on plant height and the plant height increased with the decrease of seed rates. Significant variation was also observed due to different levels of NPK. The treatment $\mathrm{N}_{30} \mathrm{P}_{24} \mathrm{~K}_{15} \mathrm{~kg} / \mathrm{ha}$ produced the significantly tallest plant $(111.52 \mathrm{~cm})$ (Table 10$)$. The plot with no fertilizer $\left(\mathrm{N}_{0} \mathrm{P}_{0} \mathrm{~K}_{0} \mathrm{~kg} / \mathrm{h}\right)$ produced significantly shortest plant $(91.34 \mathrm{~cm})$, which was inferior to all other treatment (Table 8). The interaction gave significantly tallest plant (111.52 cm) (Table 10). The plot with no fertilizer $\left(\mathrm{N}_{0} \mathrm{P}_{9} \mathrm{~K}_{0} \mathrm{~kg} / \mathrm{ha}\right)$ produced significantly shortest plant $(91.34 \mathrm{~cm})$, which was inferior to all other treatments (Table 8). The interaction effect of seed rates and levels of NPK was significant on plant height. Effective tillers per plant showed no significant variation for different seed rates. The 
highest tillers/plant (1.05) was recorded in $14 \mathrm{~kg}$ seed/ha and the lowest (1.03) from $10 \mathrm{~kg}$ seed/hill. The response of effective tillers per plant to different levels of NPK was not significant too (Table 10). However, apparently highest tillers per plant was recorded in $\mathrm{N}_{0} \mathrm{P}_{8} \mathrm{~K}_{5} \mathrm{~kg} /$ ha and the lowest in $\mathrm{N}_{20} \mathrm{P}_{16} \mathrm{~K}_{10} \mathrm{~kg} / \mathrm{ha}$ The interaction effect of seed rates and levels of NPK had significant effect on effective tillers per plant. The overall results are in agreement with Horliuchi et al., 1986 who reported that tillering of foxtail millet is generally low and could not be altered significantly. The longest $(14.44 \mathrm{~cm})$ and the shortest $(13.67 \mathrm{~cm})$ panicle length were obtained from $8 \mathrm{~kg}$ seed/ha and $14 \mathrm{~kg}$ seed/ha, respectively (Table 7). The longest panicle length with $8 \mathrm{~kg}$ seed/ha may be due to minimum plant population resulting in good development of the plant and gave longer panicle length. On the contrary, in case of NPK levels, the longest $(15.40 \mathrm{~cm})$ and the shortest $(12.28 \mathrm{~cm})$ panicle length were produced by the treatment of $\mathrm{N}_{0}{ }_{0} \mathrm{P}_{32} \mathrm{~K}_{20} \mathrm{~kg} / \mathrm{ha}$ and $\mathrm{N}_{0} \mathrm{P}_{0} \mathrm{~K}_{0}$, respectively. It was evident from the results that panicle length increased with increasing levels of NPK. The interaction of seed rate and levels of NPK was significant in respect of panicle length (Table 9). In case of number of grains/panicle, the maximum (2506 panicle) and the minimum (2070 ) number of grains were found in $8 \mathrm{~kg}$ seed and $14 \mathrm{~kg}$ seed, respectively (Table 7). Number of grains/panicle decreased with increasing seed rate. This might be due to high competition of the crop for light, space, nutrition, and soil moisture, under higher seed rates leading to reduce the number of grains/panicle. In case of NPK application, significantly highest number of grains panicle/ha (2902) was recorded in $\mathrm{N}_{30} \mathrm{P}_{24} \mathrm{~K}_{15} \mathrm{~kg} /$ ha while the lowest value (1591) being noted in $\mathrm{N}_{0} \mathrm{P}_{0} \mathrm{~K}_{0}$ treatment (Table 10). Results indicate that number of grains panicle/ha increased when levels of NPK increased. Cereals generally take up a large quantity of nitrogen and phosphorus for grain formulation which influences the plant growth, development, and thereafter number of grains. The number of grains panicle varied significantly due to interaction between seed rates and levels of NPK (Table 9). In case of interaction, $8 \mathrm{~kg}$ seed per ha and $\mathrm{N}_{30} \mathrm{P}_{24} \mathrm{~K}_{15} \mathrm{~kg} / \mathrm{ha}$ treatment combination produced the highest number of grains. The weight of 1000 -seed was not significantly affected by seed rate and different levels of NPK. The 1000-seed weights were $1.51,1.62,1.52$, and 1.50 for $8,10,12$, and $14 \mathrm{~kg}$ seed/ha, respectively (Table 7). Numerically the highest 1000-seed weight (1.66 g) was obtained in $\mathrm{N}_{30} \mathrm{P}_{24} \mathrm{~K}_{15} \mathrm{~kg} / \mathrm{ha}$. The lowest 1000 -seed weight $(1.31 \mathrm{~g})$ was found in $\mathrm{N}_{0} \mathrm{P}_{0} \mathrm{~K}_{0} \mathrm{~kg} / \mathrm{ha}$ (Table 10). The result are in agreement with (Beketov, 1975) who reported that application of NPK increased 1000-seed, weight. The interaction effect of seed rates and levels of NPK was not significant too in respect of 1000seed weight. 
Table 6. Effect of interaction of seed rates and different levels of NPK on stem dry matter accumulation.

\begin{tabular}{|c|c|c|c|c|}
\hline $\begin{array}{l}\text { interaction of } \\
\text { seed rates x } \\
\text { levels of NPK }\end{array}$ & $\begin{array}{c}60 \text { DAS (At } \\
\text { vegetative stage) }\end{array}$ & $\begin{array}{c}80 \text { DAS (At } \\
\text { flowering stage) }\end{array}$ & $\begin{array}{l}80 \text { DAS (At } \\
\text { dough stage) }\end{array}$ & $\begin{array}{l}102 \text { DAS (At } \\
\text { harvest) }\end{array}$ \\
\hline $\mathrm{S}_{1} \mathrm{~F}_{0}$ & $0.010 \mathrm{~h}$ & $1.150 \mathrm{~h}$ & $5.830 \mathrm{~g}$ & $18.850 \mathrm{~g}$ \\
\hline $\mathrm{S}_{1} \mathrm{~F}_{1}$ & $0.090 \mathrm{fg}$ & $1.960 \mathrm{~cd}$ & 9.480 bc & 24.450 def \\
\hline $\mathrm{S}_{1} \mathrm{~F}_{2}$ & $0.089 \mathrm{fg}$ & $1.830 \mathrm{de}$ & 7.130 ef & 24.360 def \\
\hline $\mathrm{S}_{1} \mathrm{~F}_{3}$ & $0.174 \mathrm{a}$ & 2.920 a & $12.350 \mathrm{a}$ & $31.250 \mathrm{a}$ \\
\hline $\mathrm{S}_{1} \mathrm{~F}_{4}$ & $0.087 \mathrm{fg}$ & $1.587 \mathrm{efg}$ & $10.090 \mathrm{~b}$ & 25.110 def \\
\hline $\mathrm{S}_{2} \mathrm{~F}_{0}$ & 0.096 efg & 2.120 bc & 8.090 de & $20.330 \mathrm{~g}$ \\
\hline $\mathrm{S}_{2} \mathrm{~F}_{1}$ & $0.086 \mathrm{~g}$ & 1.860 cde & $12.160 \mathrm{a}$ & 24.670 def \\
\hline $\mathrm{S}_{2} \mathrm{~F}_{2}$ & 0.110 cde & $1.790 \mathrm{de}$ & $9.980 \mathrm{~b}$ & $26.760 \mathrm{bcd}$ \\
\hline $\mathrm{S}_{2} \mathrm{~F}_{3}$ & 0.106 def & j44jg & 8.050 de & 25.580 cdef \\
\hline $\mathrm{S}_{2} \mathrm{~F}_{4}$ & $0.134 \mathrm{ab}$ & $2.352 \mathrm{~b}$ & $12.100 \mathrm{a}$ & $28.650 \mathrm{~b}$ \\
\hline $\mathrm{S}_{3} \mathrm{~F}_{0}$ & 0.094 efg & j74efg & $8.400 \mathrm{~cd}$ & 23.970 ef \\
\hline $\mathrm{S}_{3} \mathrm{~F}_{1}$ & $0.086 \mathrm{~g}$ & $1.740 \mathrm{de}$ & $8.460 \mathrm{~d}$ & $23.780 \mathrm{f}$ \\
\hline $\mathrm{S}_{3} \mathrm{~F}_{2}$ & 0.103defg & & 7.4SOdef & 26.17ocdef \\
\hline $\mathrm{S}_{3} \mathrm{~F}_{3}$ & $0.094 \mathrm{efg}$ & 1.6lOefg & 7.88Odef & 24.86Odef \\
\hline $\mathrm{S}_{3} \mathrm{~F}_{4}$ & 0.097 efg & $2.140 \mathrm{bc}$ & 11.970 a & 30.960 a \\
\hline $\mathrm{S}_{4} \mathrm{~F}_{0}$ & $0.120 \mathrm{bcd}$ & $1.960 \mathrm{~cd}$ & 7.550 def & $19.630 \mathrm{~g}$ \\
\hline $\mathrm{S}_{4} \mathrm{~F}_{1}$ & $0.120 \mathrm{bcd}$ & $1.160 \mathrm{~h}$ & $6.740 \mathrm{fg}$ & $19.830 \mathrm{~g}$ \\
\hline $\mathrm{S}_{4} \mathrm{~F}_{2}$ & 0.127 bc & & 7.570 def & 27.790 bc \\
\hline $\mathrm{S}_{4} \mathrm{~F}_{3}$ & 0.127 bc & 1.703 def & 7.420 def & 26.460 bcde \\
\hline $\mathrm{S}_{4} \mathrm{~F}_{4}$ & 0.127 bc & 1.760 de & 8.450 de & 25.560 cdef \\
\hline $\begin{array}{l}\text { Level } \\
\text { significance }\end{array}$ & 0.0020 & 0.0100 & 0.0010 & 0.0010 \\
\hline Sx & 0.0046 & 0.0688 & 0.3021 & 0.7413 \\
\hline CV (\%) & 8.71 & 8.65 & 7.91 & 7.15 \\
\hline
\end{tabular}

In a column, figures having common letter (s) do not differ significantly

Grain yield is the ultimate objectives of crop production. Seed rates significantly affected the grain yield of foxtail millet (Table 9). The highest grain yield (1.62 t/ha) was obtained from $10 \mathrm{~kg}$ seed/ha which was identical with $12 \mathrm{~kg}$ seed/ha. The lowest grain yield (1.41 t/ha) was found in seed rate $8 \mathrm{~kg} / \mathrm{ha}$. The result is in conformity with that of Sarder et al., 1987 and Gaffer, 1994 where the maximum grain yield of foxtail millet was found from 10 and $12 \mathrm{~kg}$ seed/ha, respectively. In case of NPK levels, the highest grain yield (1.77 t/ha) 
Table 7. Effect of seed rates on the yield and yield contributing characters of foxtail millet. 
Table 8. Effect of different levels of NPK on the yield and yield contributing characters of foxtail millet.

\begin{tabular}{|c|c|c|c|c|c|c|c|c|c|}
\hline \multirow[b]{2}{*}{$\begin{array}{l}\text { Fertilizers } \\
\text { (kg/ha ) }\end{array}$} & \multicolumn{9}{|c|}{ Crop characters } \\
\hline & $\begin{array}{l}\text { Plant } \\
\text { height } \\
(\mathrm{cm})\end{array}$ & $\begin{array}{l}\text { No. of } \\
\text { effective } \\
\text { tillers/ } \\
\text { plant }\end{array}$ & $\begin{array}{c}\text { Panicle } \\
\text { length } \\
\text { (cm) }\end{array}$ & $\begin{array}{c}\text { No. of } \\
\text { grains } \\
\text { panicle1 }\end{array}$ & $\begin{array}{l}\text { Weight } \\
\text { of } 1000- \\
\text { seed }(g)\end{array}$ & $\begin{array}{c}\text { Grain yield } \\
\text { (t/ha) }\end{array}$ & $\begin{array}{l}\text { Straw } \\
\text { yield }\end{array}$ & $\begin{array}{c}\text { Biological } \\
\text { yield } \\
\text { (t/ha) }\end{array}$ & $\begin{array}{c}\text { Harvest } \\
\text { index } \\
(\% \%)\end{array}$ \\
\hline $\mathrm{N}_{0} \mathrm{P}_{0} \mathrm{~K}_{0}$ & $91.34 d$ & 1.03 & $12.28 \mathrm{~d}$ & 1591d & 1.31 & $0.97 d$ & $2.65 c$ & $3.62 d$ & $26.60 d$ \\
\hline $\mathrm{N}_{10} \mathrm{P}_{8} \mathrm{~K}_{5}$ & $102.06 \mathrm{c}$ & 1.06 & 13.09c & $2044 c$ & 1.46 & $1.55 c$ & $3.75 b$ & $3.31 \mathrm{c}$ & $28.94 b$ \\
\hline $\mathrm{N}_{20} \mathrm{P}_{16} \mathrm{~K}_{10}$ & 106.33b & 1.01 & $14.17 b$ & 2281c & 1.63 & $1.65 \mathrm{~b}$ & $3.91 b$ & $5.55 b$ & $29.64 a$ \\
\hline $\mathrm{N}_{30} \mathrm{P}_{24} \mathrm{~K}_{15}$ & II 1.52a & 1.06 & $15.35 a$ & $2902 a$ & 1.66 & $1.77 \mathrm{a}$ & $4.49 a$ & $6.26 \mathrm{a}$ & $28.18 \mathrm{c}$ \\
\hline $\mathrm{N}_{40} \mathrm{P}_{32} \mathrm{~K}_{20}$ & 108.89ab & 1.05 & $15.40 \mathrm{a}$ & $2776 \mathrm{~b}$ & 1.64 & $1.6 \mathrm{Obc}$ & $4.56 a$ & $6.16 a$ & $25.88 \mathrm{c}$ \\
\hline $\begin{array}{l}\text { Level of } \\
\text { significance }\end{array}$ & 0.0001 & NS & 0.00001 & 0.00001 & NS & 0.00001 & 0.0001 & 0.00001 & 0.00001 \\
\hline Sx & 1.252 & 0.032 & 0.224 & 22.36 & 0.0645 & 2.24 & 6.46 & 6.74 & 0.199 \\
\hline Cv (\%) & 4.17 & 10.76 & 5.51 & 8.34 & 14.52 & 8.14 & 5.77 & 5.34 & 5.47 \\
\hline
\end{tabular}

In a column, figures having common letter(s) do not differ significantly.

NS= Non Significant. 
Table 9. Effect of interaction of seed rates and different levels of NPK on the yield and yield contributing characteristics of foxtail millet.

\begin{tabular}{|c|c|c|c|c|c|c|c|c|c|}
\hline $\begin{array}{l}\text { Interaction } \\
\text { of seed } \\
\text { rates } \times \\
\text { level of } \\
\text { NPK }\end{array}$ & $\begin{array}{l}\text { Plant } \\
\text { height } \\
(\mathrm{cm})\end{array}$ & $\begin{array}{c}\text { No. of } \\
\text { effective } \\
\text { tillers/ plant }\end{array}$ & $\begin{array}{c}\text { Panicle } \\
\text { length }(\mathrm{cm})\end{array}$ & $\begin{array}{l}\text { No. of } \\
\text { grains/ } \\
\text { panicle }\end{array}$ & $\begin{array}{l}\text { Weight } \\
\text { of 1000- } \\
\text { seed (g) }\end{array}$ & $\begin{array}{c}\text { Grain yield } \\
\text { (t/ha) }\end{array}$ & $\begin{array}{c}\text { Straw yield } \\
\text { (t/ha) }\end{array}$ & $\begin{array}{l}\text { Biological } \\
\text { yield } \\
\text { (t/ha) }\end{array}$ & $\begin{array}{c}\text { Harvest } \\
\text { index } \\
(\%)\end{array}$ \\
\hline $\mathrm{S}_{1} \mathrm{~F}_{0}$ & 91.69 ef & 1.000 & $12.56 \mathrm{fg}$ & $1650 \mathrm{j}$ & 1.36 & $1.00 \mathrm{i}$ & 2.85 hi & $3.85 \mathrm{ii}$ & $25.97 \mathrm{f}$ \\
\hline $\mathrm{S}_{1} \mathrm{~F}_{3}$ & 113.43 a & 1.060 & $16.24 \mathrm{a}$ & 3319 a & 1.55 & $1.83 \mathrm{~cd}$ & $4.66 \mathrm{c}$ & 6.49 hc & $28.20 \mathrm{e}$ \\
\hline $\mathrm{S}_{1} \mathrm{~F}_{4}$ & $105.52 \mathrm{abc}$ & 1.170 & $15.69 \mathrm{ab}$ & $2824 \mathrm{~cd}$ & 1.64 & $1,08 \mathrm{i}$ & $3.63 \mathrm{fg}$ & $4.71 \mathrm{~h}$ & $22.95 \mathrm{~g}$ \\
\hline $\mathrm{S}_{2} \mathrm{~F}_{0}$ & $92.56 \mathrm{ef}$ & 1.100 & $12.06 \mathrm{~g}$ & $1598 \mathrm{j}$ & 1.31 & $0.68 \mathrm{j}$ & $2.55 \mathrm{ij}$ & $3.23 \mathrm{k}$ & $21.13 \mathrm{~h}$ \\
\hline $\mathrm{S}_{2} \mathrm{~F}_{3}$ & $111.07 \mathrm{a}$ & 1.000 & $14.73 \mathrm{bcd}$ & 2710 de & 1.69 & 1.76 de & $4.50 \mathrm{~cd}$ & $6.26 \mathrm{bcd}$ & 28.19 e \\
\hline $\mathrm{S}_{2} \mathrm{~F}_{4}$ & $105.06 \mathrm{abc}$ & 1.000 & 15.09 abc & 2576 e & 1.55 & $1.80 \mathrm{de}$ & $3.36 \mathrm{~cd}$ & $6.16 \mathrm{~cd}$ & 29.19 de \\
\hline $\mathrm{S}_{3} \mathrm{~F}_{0}$ & 95.11 de & 1.000 & 12.76efg & 1848 i & 1.30 & $1.12 \mathrm{i}$ & 2.78 hig & 3.90 & 28.96 de \\
\hline $\mathrm{S}_{3} \mathrm{~F}_{1}$ & 99.10 cde & 1.100 & 13.76 def & $2127 \mathrm{~g}$ & 1.25 & $1.08 \mathrm{i}$ & $3.03 \mathrm{~h}$ & $4.11 \mathrm{i}$ & $26.32 \mathrm{f}$ \\
\hline $\mathrm{S}_{3} \mathrm{~F}_{2}$ & $109.52 \mathrm{ab}$ & 1.000 & 13.94 cdef & $231 \mathrm{Sf}$ & 1.57 & $1.66 \mathrm{ef}$ & 3.91 ef & 5.58 ef & $29.85 \mathrm{~cd}$ \\
\hline
\end{tabular}




\begin{tabular}{|c|c|c|c|c|c|c|c|c|c|}
\hline $\begin{array}{l}\text { Interaction } \\
\text { of seed } \\
\text { rates } \times \\
\text { level of } \\
\text { NPK }\end{array}$ & $\begin{array}{l}\text { Plant } \\
\text { height } \\
(\mathrm{cm})\end{array}$ & $\begin{array}{c}\text { No. of } \\
\text { effective } \\
\text { tillers/ plant }\end{array}$ & $\begin{array}{c}\text { Panicle } \\
\text { length }(\mathrm{cm})\end{array}$ & $\begin{array}{l}\text { No. of } \\
\text { grains/ } \\
\text { panicle }\end{array}$ & $\begin{array}{l}\text { Weight } \\
\text { of } 1000- \\
\text { seed (g) }\end{array}$ & $\begin{array}{l}\text { Grain yield } \\
\text { (t/ha) }\end{array}$ & $\begin{array}{c}\text { Straw yield } \\
\text { (t/ha) }\end{array}$ & $\begin{array}{c}\text { Biological } \\
\text { yield } \\
\text { (t/ha) }\end{array}$ & $\begin{array}{c}\text { Harvest } \\
\text { index } \\
(\%)\end{array}$ \\
\hline $\mathrm{S}_{3} \mathrm{~F}_{3}$ & 113.55 a & 1.060 & 15.O8abcd & 2989b & 1.81 & $2.15 \mathrm{a}$ & $5.16 \mathrm{~b}$ & $7.31 \mathrm{a}$ & $29.38 \mathrm{~cd}$ \\
\hline $\mathrm{S}_{4} \mathrm{~F}_{0}$ & $85.74 \mathrm{f}$ & 1.00 & $11.72 \mathrm{~g}$ & $1268 \mathrm{k}$ & 1.27 & $1.06 \mathrm{i}$ & $2.41 \mathrm{j}$ & $3.48 \mathrm{jk}$ & 30.62 c \\
\hline $\mathrm{S}_{4} \mathrm{~F}_{1}$ & 91.72 ef & 1.130 & $11.58 \mathrm{~g}$ & $1699 j$ & 1.32 & $1.48 \mathrm{~g}$ & $3.55 \mathrm{fg}$ & $5.03 \mathrm{gh}$ & 29.47 cd \\
\hline $\mathrm{S}_{4} \mathrm{~F}_{2}$ & $108.03 \mathrm{ab}$ & 1.000 & 13.92 cde & 1949 hi & 1.67 & $1.55 \mathrm{fg}$ & $4.36 \mathrm{~cd}$ & $5.91 \mathrm{de}$ & $28.20 \mathrm{f}$ \\
\hline Sx & 2.5033 & 0.064 & 0.447 & 44.721 & 0.129 & 4.472 & 12.909 & 13.739 & 0.3979 \\
\hline CV (\%) & 4.17 & 10.76 & 5.51 & 8.34 & 14.52 & 8.14 & 5.77 & 5.34 & 5.47 \\
\hline
\end{tabular}


was found in $\mathrm{N}_{30} \mathrm{P}_{24} \mathrm{~K}_{15} \mathrm{~kg} /$ ha which was identical with $\mathrm{N}_{20} \mathrm{P}_{16} \mathrm{~K}_{10} \mathrm{~kg} /$ ha (Table 8). The grain yield gradually increased with increasing levels of NPK. The result is in agreement with (Vyas et al., 1994) who reported that when fertilizer rates increased the yield also increased. The highest grain yield (2.15 t/ha) was recorded from the combination $12 \mathrm{~kg}$ seed/ha and $\mathrm{N}_{30} \mathrm{P}_{24} \mathrm{~K}_{15} \mathrm{~kg} / \mathrm{ha}$ (Table 9). Straw yield and as well as biological yield were also significantly influenced by seed rates, levels of NPK and their interaction. The highest straw yield (4.09 t/ha) and biological yield (5.61 t/ha) were obtained from seed rate $12 \mathrm{~kg} / \mathrm{ha}$. In case of NPK levels, the highest straw yield (4.56 t/ha) and biological yield (6.26 t/ha) were found in $\mathrm{N}_{40} \mathrm{P}_{32} \mathrm{~K}_{20}$ and $\mathrm{N}_{30} \mathrm{P}_{24} \mathrm{~K}_{15} \mathrm{~kg} /$ ha treatments, respectively. The highest straw yield (5.34 t/ha) and biological yield (7.31 t/ha) were obtained from the combination $12 \mathrm{~kg}$ seed/ha and $\mathrm{N}_{40} \mathrm{P}_{32} \mathrm{~K}_{20} \mathrm{~kg} / \mathrm{ha}$ which was identically followed by $12 \mathrm{~kg}$ seed/ha and $\mathrm{N}_{30} \mathrm{P}_{24} \mathrm{~K}_{15} \mathrm{~kg} / \mathrm{ha}$ (Table 11). The results are in partial agreement with (Dhillon and Panwar, 1976) who observed that straw yield and biological yield increased with increasing NPK fertilizer. The impacts of seed rate and NPK application in harvest index of the crop was significant (Table 3 and 4).

The highest harvest index (29.94) was obtained from $10 \mathrm{~kg}$ seed/ha which was identically followed by $14 \mathrm{~kg}$ seed/ha. In case of NPK levels, the highest harvest index (29.78) was found in $\mathrm{N}_{20} \mathrm{P}_{16} \mathrm{~K}_{10} \mathrm{~kg} / \mathrm{ha}$, which was identical with $\mathrm{N}_{10} \mathrm{P}_{8} \mathrm{~K}_{5} \mathrm{~kg} / \mathrm{ha}$. The interaction of seed rates and levels of NPK was significant on harvest index (Table 9).

From the overall results obtained in the study indicated that $\mathrm{N}_{30} \mathrm{P}_{24} \mathrm{~K}_{15} \mathrm{~kg} / \mathrm{ha}$ and $10 \mathrm{~kg}$ seed/ha might be used to obtain satisfactory yield of foxtail millet $\mathrm{cv}$. Titas under the prevailing agroclimatic conditions of BAU farm of Old Brahmaputra Floodplains soils (AEZ-9).

\section{References}

Anonymous. 1990. "Kanoer Natun Jat Titas". A leaflet Pub. by Plant Breeding Division, Bangladesh Agril. Res. Inst., Joydebpur, Gazipur-1707. Pp.3-4.

BARI (Bangladesh Agricultural Research Institute). 1985. Annual Report (1983-84). Bangladesh Agricultural Research Institute, Joydebpur, Gazipur-1 707. Pp.30-31.

BARI (Bangladesh Agricultural Research Institute). 1990. Final Report. Millets Improvement Project. Plant Breeding Division, Bangladesh Agricultural Research Institute, Joydebpur, Gazipur-1707. Pp.2.

BBS (Bangladesh Bureau of Statistics). 1993. Statistical Year Book of Bangladesh. Statistics Division, Ministry of Planning, Government of the People's Republic of Bangladesh. P. 176.

Benner, B.L. and Bazzaz, F. A. 1988. Carbon and Mineral accumulation and allocation in two annual plant species in response to timing of nutrient addition. J. Ecol. 72:19-40. 
Coscia, A. A. 1983. The grains of foxtail millet, its uses and marketing possibilities. Estacion Experimental Regional Agropecuria Pergamino, INTA, Pergamino, Argentina. 172: 15.

Dhillon, G. S. and B. S. Panwer. 1976. Fertilizer requirments of Cheena. Indian J. Agron. 21(4):396-400.

Elias, J. B., A. A. Gazianas and P. A. Gerakis. 1979. Interrelationship and plasticity of growth parameters in Zea mays L. as influenced by density and nitrogen. Oecol. Plantarum 14: 159-168.

FAO (Food and Agriculture Organization). 1985. FAO Production Year Book, 39: 120 Rome.

Gaffer, M. A. 1994. Development of management practices of millets for higher production. BAU Res. Prog. 8: 14-18.

Hedge, B. R. and B. K. L Gowda. 1986. Cropping system and production technology for small millets in India. Paper presented at the International Workshop on Small Millets in Bangalore, India, 29 Sep. Oct. 3, 1986.

Horliuchi, T., M. Nakamichi and T. Takano. 1986. Studies on corresponded relationship between plant characters and cultivation method, VI Tillering behaviour and ability of Italian millet. Research Bull. of Agriculture. Gifu University, (Japan). 51: 1-12.

Mannujan, M., S. Sarker and M. M. Hoque. 1990. Performance of foxtail millet germplasm in Bangladesh. Bangladesh J. Agril. Res. 15(1): 65-67.

Munda, G.C., M. Pal and S. L. Pandey. 1984. Effect of nitrogen and phosphorus on dry matter accumulation and nutrient uptake pattern in hybrid pearl millet. Indian $J$. Agron. 29(2): 185- 198.

Naik, B., T. B. K. L. Gowda, S. T. Gowda. and S. Sridhara. 1995. Effect of integrated nutrient management on growth and grain yield of foxtail millet (Setaria italica $\mathrm{L}$. Beauv.) under rainfed conditions on Alfisols of sub tropical India. Fertilizer News 40(3): 555-57.

Sarder, F., A. Hossain and S. H. Hawlader. 1987. Study on the seed rates and fertilizer rates of Kaon. Bangladesh Association for the advancement of science. Proceeding of the 12th Annual Bangladesh Science Conference, Section -1. Dhaka 1987. P. 8.

Takanohashi, T. 1993. Millet as health. Farming Japan 27(4): 27.

Vyas, S. H., J. C. Patel, B. S. Patel and V. D. Khanpara. 1994. Influence of irrigation and NP fertilization on yield of summer pearl millet in South Sourashtra region. Gujrat Agril. Univ. Res. J. 19(2): 113-16. 